\title{
Representation of Orientalism in Sunsilk Print Advertising
}

\section{Representasi Orientalisme dalam Iklan Cetak Sunsilk}

\author{
Hilma Rizky Nurcahya ${ }^{1}$, Hanny Hafiar ${ }^{1}$, Aat Ruchiat Nugraha ${ }^{1}$ \\ ${ }^{1}$ Faculty of Communication Sciences, Universitas Padjadjaran, Jl. Raya Bandung \\ Sumedang KM 21, Jatinangor 45363, Indonesia \\ *Corresponding author, e-mail: hilmarizkyn@gmail.com
}

\begin{abstract}
Using the qualitative method, the critical paradigm, and also Roland Barthes semiotic analysis, this study aims to find out the symbols contained in Sunsilk Co-creations print advertising, the meaning contained in the symbols and how the symbols subordinate the Eastern people. The results of this study indicate that there are seven symbols in Sunsilk Co-creations version print advertising that has unity meaning, i.e there are dominant people who are showed as more superior thus there are other people who are considered inferior. With the myth that the West is better seen as the superior and the East is seen as the inferior, then the symbols and meanings in Sunsilk Co-creations print advertising represent orientalism. The researchers suggest to pay attention to the symbols that will be aired so as not to be negative because it can affect the reputation of the company/institution concerned. Besides that, it is expected to the Eastern people especially Indonesian to be able to change their thought to be more proud and show their confidence.
\end{abstract}

Keywords: Roland Barthes Semiotic, Orientalism, Print Advertising, Sunsilk Co-creations.

\begin{abstract}
Abstrak
Dengan menggunakan metode kualitatif, paradigma kritis, dan dengan menggunakan analisis semiotika Roland Barthes, penelitian ini bertujuan untuk mengetahui simbol-simbol yang terdapat dalam iklan cetak Sunsilk versi Co-creations, makna yang terkandung dalam simbol-simbol dan bagaimana simbol tersebut mensubordinatkan kaum Timur. Hasil dari penelitian ini menunjukkan terdapat tujuh simbol dalam iklan cetak Sunsilk versi Co-creations yang memiliki kesatuan makna yaitu terdapat kaum dominan yang ditampilkan seolah lebih super sehingga terdapat kaum lainnya yang dipandang lebih rendah. Dengan mitos bahwa Barat lebih dipandang sebagai kaum superior dan Timur dipandang sebagai kaum inferior, maka simbol dan makna dalam iklan cetak Sunsilk versi Co-creations merepresentasikan orientalisme. Saran dari penelitian ini diharapkan dapat memperhatikan simbol-simbol yang akan ditayangkan agar tidak bermakna negatif karena dapat memengaruhi reputasi perusahaan/lembaga yang bersangkutan. Selain itu, diharapkan kepada kaum Timur terutama Indonesia dapat mengubah pemikirannya agar berkemauan untuk lebih bangga dan menunjukkan kepercayaan dirinya.
\end{abstract}

Kata Kunci: Semiotika Roland Barthes, Orientalisme, Iklan Cetak, Sunsilk Co-creations.

Copyright (C) 2018 Universitas Semarang. All rights reserved.

\section{Introduction}

Sunsilk is one of the products of PT. Unilever Indonesia, Tbk which launched an innovation of its product namely Sunsilk Co-creations version shampoo for the first time on June 2010. In its innovation, Sunsilk works with 7 world-class hair experts to produce the best shampoo formulation, with the blend of natural ingredients and the latest technology to answer the needs of Indonesian women hair care. Of course the

Article History: Received December 23, 2017; Revised January 17, 2018; Accepted June 9, 2018; Published July 31, 2018 
innovation of this product needs to be communicated to the public who become the target. To achieve the target, one of them is through advertising.

Based on the results of interview with PT. Unilever, Pandeka, as Unilever's Brand Development on October 20, 2016 in Jakarta that Sunsilk Co-creations advertising is conceptualized by Sunsilk Global Brand Development department. This means that the central core team has tasks in the field of product innovation, communication innovation, including drafting and creating advertising and other assets after being run by Brand Building (BB) whose position in business in every country is for the execution and the dissemination, including Indonesia.

Advertising as a form of marketing communication would need to be considered thoroughly. Indirectly, the advertising displayed has meaning when received by the audiences. Signs can be analyzed using semiotic method because semiotic method analyzes the related symbols to become an interpretable message. The signs in discussion are often considered as an individual or stand-alone sign. However, when we note further, the signs are related to each other in a relationship that makes it a unity in a system, which can be referred to as sign system (Nuswantara, 2014).

This time, we discuss Sunsilk Co-creations advertising on local printed media (Indonesia) that rises several symbols which can be drawn into the seven symbols to be studied. The first is the selection of 7 models of foreign models and 7 hair experts, the text of the statement contained above the image, namely 'Partnered With 7 Of The Best Experts in The World - To Create The Best Ever Sunsilk', the gesture shown by model, i.e the keen gaze, cuffing waist, inserting hands into pants pocket, and folding hands across the chest, then the facet of business casual fashion model used by the models, typography on 'SUNSILK CO-CREATIONS' writing with lights ornament, and plain black background shown in the following Sunsilk Co-creations print advertising:

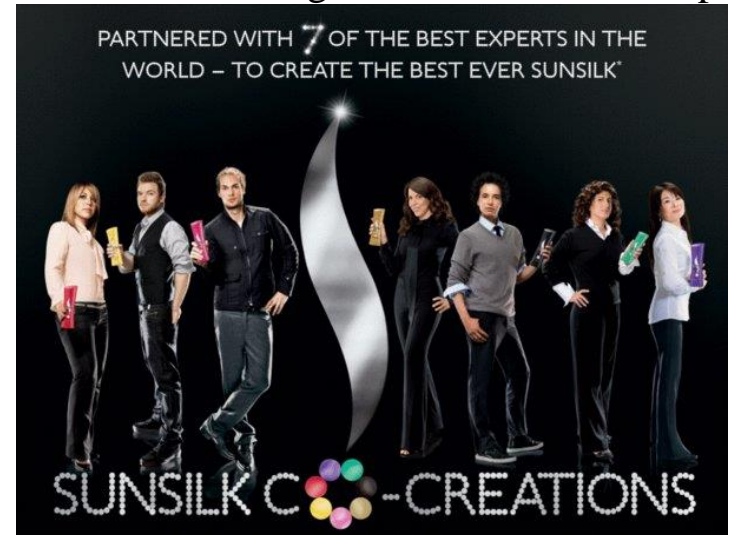

Image 1. Sunsilk Co-creations Print Advertising

(Sunsilk, 2016)

In Sunsilk Co-creations print advertising above, there are 7 (seven) hair experts who cooperate with Sunsilk. Starting from the left of the photo is Rita Hazan, via the website https://ritahazan.com/ who becomes one of the trusted colour care expert in New York, proven by handling some famous Hollywood hair artists and own salon. The next is Thomas Taw who is proclaimed as an expert in hair damage treatment. Thomas Taw is a hairdresser and businessman from London. Sunsilk sent Thomas Taw as damage care expert (Sunsilk, 2010). Another hair expert is Teddy Charles from Paris, with the background of working with world-renowned photographer while young. Sunsilk honored Teddy as shape expert or hair care to be more volume (Sunsilk, 2016). 
Francesca Fusco is a graduate of New York Medical College and becomes a famous dermatologist and scalpologist, so that he becomes one of co-created scalp care expert Sunsilk (Wexlerdermatology, 2016). Jamal Hammadi is from California. He has experience in creating sensual and glamorous hairstyle for Hollywood artists. $\mathrm{He}$ cooperates with Sunsilk as co-created Shine Expert (Hamadibeauty, 2016).

Ouidad is hair expert who won the best stylist award to release his own product under the name Ouidad. With his achievement as a stylist for curly hair specialties, Ouidad becomes Sunsilk co-creared Curls Expert (Ouidad, 2016). The last hair expert, named Yuko Yamashita, is the only co-created from Asia, namely Tokyo. He created Yuko Hair Straightening in Japan in 1996. Therefore, Sunsilk made Yuko co-created Straight Expert (Sunsilk, 2016).

From the Sunsilk Co-creations advertising, there are things that are considered interesting to be criticized and discussed. From the 7 hair experts proclaimed by Sunsilk as world-class hair expert, only one hair expert is from the East, i.e Yuko, and the other six are hair experts from the West. It is supported by some other symbols that have the meaning of dominating. According to the researchers, there is an imbalance of portion in the advertising such as model selection which dominates in Sunsilk Co-creations print advertising marketed in Argentina, Bangladesh, Bolivia, Brazil, Central America, Chile, Greece, India, Indonesia, Italy, Mexico, Paraguay, Peru, Philippines, Thailand, Turkey, Uruguay and Vietnam (Sunsilk, 2016).

According to the data above, it is mentioned that Indonesia is one of the marketing target countries of Sunsilk Co-creations product that automatically the advertising is displayed in Indonesia. In Indonesia itself there is actually famous hair expert and a businessman, salon owner, to have his own products, namely Rudy Hadisuwarno.

Based on the background, the experience of the seven people actually can be said not much different from Rudy, even it can be said that actually the experience and the achievement of Rudy is superior to some of the best experts proclaimed by Sunsilk. From that reality, the idea arose that there were reasons for the selection of the seven people who worked with Sunsilk on Sunsilk Co-creations advertising.

If it is examined further, there are parties subordinated here, namely the hair experts from the East especially Indonesia and there are parties who are considered dominant, namely the hair experts from the Western region. So, it can be said that Indonesia is only as place of distribution or sale of its products, not as the executor (Pandeka, Brand Development of Unilever, October 2016). It leads to the capitalist at the end.

There is something to be discussed here, that is how Westerners use the background of thought that sees their people (Western society) is more powerful than the Eastern society or so-called orientalism. According to Edward Said in http://mohammad-darry-fisip12.web.unair.ac.id/ (accessed on May 21, 2016), orientalism is the Western way to dominate, restructure, and control over the Eastern. So, the division of the world is divided into West and East only.

Basically, the meanings of thought about the Eastern and the Western world do not appear without clear basis. The meaning of these two geographical boundaries is also not just the reading without content and the veiled ideas. The East and West relations in depth is the attachment between power and knowledge. The postcolonial figure, Edward Said, in his phenomenal book, 'Orientalism' (1978) reveals that with the Western-made knowledge, the Eastern adopt the idea that they are 'exotic, pure, beautiful, the guardian of hereditary cultures' (Stephanie, 2014). 
The statement can be interpreted as the cause - effect of colonialism or the colonization that most Westerns do to the Eastern people. So, it can be observed that orientalism is the science that sees the difference in contrast between Western society and Eastern society. The Eastern society is seen by the Western society as an object of discourses colonial which is opposite to the West that can not be separated from the influence of power and knowledge.

Unconsciously, colonialism is still going on, but in a subtle way. Colonialism is not carried out coercively (violence), but by hegemony in a mode of influencing the mental realm of people's awareness through hereditary cultures using the primary means such as in medias by example advertising, since advertising as part of the visual medium is capable of 'influencing perceptions and building impressions' (Hafiar, Mahameruaji \& Rahmawan, 2017).

The reality in general happening today lies in the minds of Eastern society, especially Indonesia, which mostly view that Western society is more dominant, excellent, superior or powerful than their own. Just like what Said 1994 points out, that Orientalism builds orientations with spesific social and cultural features different from the West. 'Orientalists use narratives constructing the Orient with specific social and cultural traits different from the West' (Taha, 2014). According to the researchers, this problem is in the hereditary mindset and not open of thought and awareness of Eastern society in utilizing what is owned because meaning becomes the issue of sign association with the code of other cultural meanings. When connotation is naturalized as something hegemonic, i.e when it is accepted 'normally' and 'naturally', it acts as the conceptual meaning map by which one understands his world. Barker said it all a myth (Fanani, 2011).

This study was conducted with the intention to provide new insights and new ideas by straightening the hereditary thought that makes the difference between East and West. The researchers want to straighten the minds of the people that Western society does not always become the dominant party and the Eastern society is subordinated or underestimated. So Western society can not underestimate the Eastern society anymore.

\section{Methodology}

This research uses qualitative method with Roland Barthes semiotic analysis and critical paradigm. The assumptions underlying the use of critical paradigm in this study are caused by the issue of symbols and how the symbols subordinate the Eastern people. Critical theory itself is characterized by three things, namely: (1) trying to grasp the taken for granted system, power structure, and ideology that dominates in the life of society; (2) revealing the oppressive rules of power and social conditions to create emancipation or more free condition of society; and (3) the existence of conscious effort to unite theories and actions (Littlejohn \& Foss, 2008).

The data collection techniques used are observation, library research, and interviews. Data analysis technique used the model and stage of Roland Barthes twostage significance. For the technique of data validity used source triangulation, where the object of research is Sunsilk Co-creations advertising. For the research site was at Unilever Indonesia and research time was from October 2016 - June 2017. 


\section{Result and Discussion}

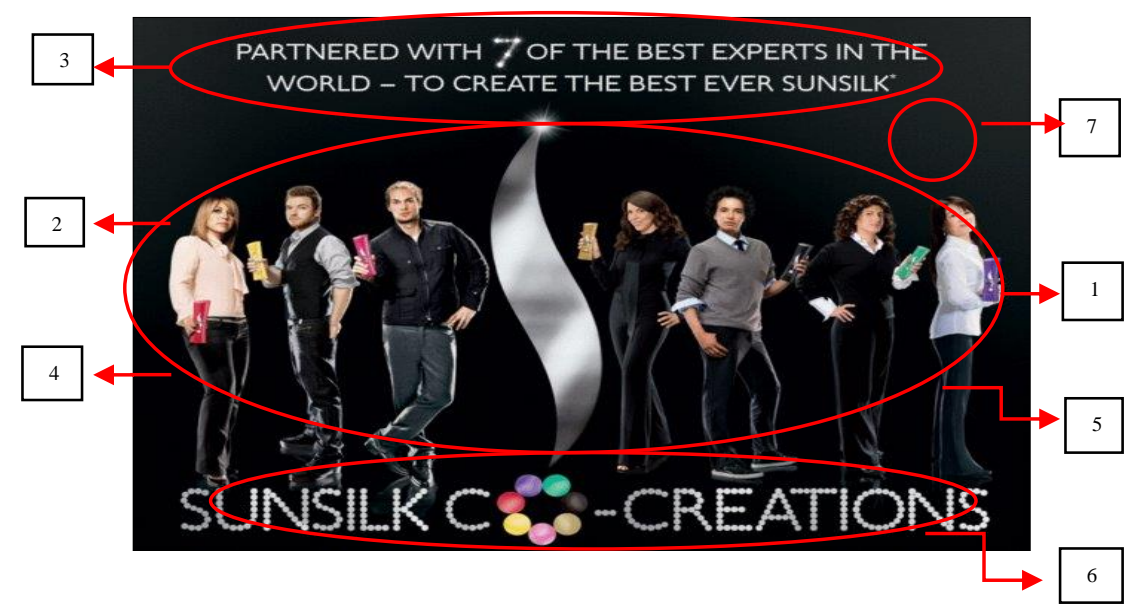

Image 2. Symbol of Sunsilk Co-creations Print Advertising

(Sunsilk, 2016)

\section{Symbol of 7 Foreigner Models}

The first symbol is the seven models who have characteristics of stranger shown by the physical and the posture of the seven people displayed. Sharp nose, hollow eyes, and white skin characterize a European-born ancestor, 'people who have lived hundreds of years in India, Polynesia, Northern Japan, and South and North America also have similar features with slightly darker skin' (Olson, 2002).

The choice of foreigners or non-Indonesians to be the model of Sunsilk Cocreations print advertising has the meaning that foreign models are more desirable to display and attract consumers. This is supported by the statement on the model of Mens Health magazine, i.e 'with a face that looks like western or mulatto which gives rise to the appearance of semi-Indonesian is seen as an ideal form of good looking' (Azis, Cangara \& Bahfiarti, 2015).

According to one production house that was founded from 1990 named Markaz Production, to become a photo model, height is not a problem. Skin and eyes are not the requirements to be a model. Usually they must have $4 \mathrm{~B}$ terms: brain, beauty, behavior, and brave (Markaz-production, 2017). In addition, the most important thing to be a model according to Leonardo Lahindo from Leonard Modeling School and Management said, expressions and can appear confident are important points that must be considered. That way, they are able to bring themselves as they are. If the heart is good it will shine out good. Based on some of the above statements, it can be argued that the model eligible to appear in the advertising does not have to be Caucasians, the most important things are distinctive and confident. Therefore, Indonesians should be able to explore their strengths and be open minded.

\section{7 Models of Hair Experts}

The reader will see 7 people standing in the middle of Sunsilk logo. The seven people are hair experts who work with or for Sunsilk. According to Williamson on semiotic theory, 'advertising adheres to the principle of sign lending as well as social code borrowing. For example, an advertising featuring a famous movie star, the movie star's figure is borrowed his myth, his ideology, his image, and the glamorous nature of the movie star' (Piliang, 2003). 
The appearance of 7 hair experts on Sunsilk Co-creations print advertising has the meaning that the choosing of experts as the model can increase the interest and the trust of the audience, supported by Sumarwan opinion that the appearance of experts in advertising a product/service is expected to give confidence to consumers regarding to the products and services advertised (Sumarwan, 2003).

The consumer's choice of brand is also heavily influenced by the association between brand and attribute or with emotional element that are usually created and contained in advertising. Some products do not use elemental ratios such as product functionality, pricing, and durability, but use appeal like prestige, convenience and the like in their advertising. So that consumers are expected to buy products for emotional reasons (Wardyaningrum, 2012).

By the way of the experts appearance, it is hoped that Indonesian people will believe in someone's expertize without seeing the truth. When we over-glorify a person or a party, we will lose the logic of the truth. So anything that comes out of it, we will always just swallow it (Idntimes, 2017). Indonesian people should be more critical and understand the information validly, as one psychologist states that theoretically, according to Laras, a person's vulnerability to the truth of information is more dependent on the ability of critical thinking, evaluating information, and media literacy, not just the skills of using information technology (Kompas, 2017).

3. 'Partnered with 7 of The Best Experts in The World - to Create The Best Ever Sunsilk' Text Symbol

Text also has an important role in an advertising. The text symbol in question is 'Partnered with 7 of The Best Experts in The World - to Create The Best Ever Sunsilk'. The inclusion of text in an advertisement is considered important. Because at least the language serves as a tool to interpret what we see. Advertisement language is also persuasive, always try to arouse the emotion of the readers, the listeners or the spectators. The goal is that the target of advertising (consumers) do something or act in accordance with the advertisement's mandate (Pebrianti, 2013).

The meaning of the word expert listed in the Cambridge Dictionary is a person with a high level of knowledge or skill relating to a particular subject or activity. In the Indonesian language expert can be regarded as 'pakar' or 'ahli'. So, the meaning of expert in the Sunsilk printed advertisement is someone who has the knowledge, certain ability. By the use of English, it can indoctrinate to judge that the use of English is more classy. This is reinforced by the statement: 'Indonesian is getting more and more active in speaking foreigners language as if to forget the language of their own to look great' (Unair, 2017).

In addition, the text includes superlative sentences, such as number 1 and best which means it violates the advertising code of ethics due to the lack of supporting data. The Sunsilk party does not display a series of achievements or certificates proving that they are working with valid persons referred to as "The Best Expert in The World". As stated in the Indonesian Advertising Ethics (Etika Pariwara Indonesia) of the 2014 amendment by the Indonesian Pariwara Board (Dewan Pariwara Indonesia) on page 23 in the sub chapter language point 1.2.2 says 'The advertisement should not use superlative words such as 'most', 'number one', 'top', and/or equally meaningful words unless accompanied by evidence that can be accounted for'.

There are many people who are more recognized and have authentic evidence to be said as an expert. Indonesia itself has hair expert who has experience and appreciation than the world-class hair expert selected by sunsilk, namely Rudy 
Hadisuwarno. He used to serve as Vice Asian President of ICD--Asia Region by 'Intercoiffure', a worldwide association of professional hairdressers based in Paris. Since 1998 Rudy Hadisuwarno's name has been recorded in the book 'Who's Who in the World' which listed him as one of the leading and most successful people in his field on an international scale. In 1968 he founded PT. Rudy Hadisuwarno, engaged in facial beauty and hair. To date, Rudy Hadisuwarno has had a total number of businesses in the supervision and management of more than 147 business units throughout Indonesia, including beauty salons, schools and academy (Rudyhadisuwarno, 2017).

Therefore, the use of foreign language, the use of the word superior, and the way Sunsilk labeled world-class hair expert to the seven people who appear in advertisement seem to take advantage of Indonesia without thinking about the effects or the result of the emergence of it leads to the negative.

4. Gesture Symbol of Model Wipes Waist, Inserting Hands into Pants Pocket, Folding Hands Across Chest, and Sharp Eye Look

Gesture is usually consciously or not can indicate the position and circumstances that exist. Mead says 'The gesture is that phase of the individual act to which adjustment takes place on the part of other individuals in the social process of behavior' (Nöth, 1995). In this study, gestures were found in waist-cuffing, inserting hands into pants pocket, folding hands across chest on gestural message, and smile on the facial message. Based on the research, body language becomes the more paid attention and achieves the most optimal and effective results in communicating with someone (Academia, 2017).

By showing the gesture of waist-cuffing, usually interpreted as a person who feels superior because indicated by his attitude that wants to dominate or control the situation. He is the one who wants to affirm his power, Without a word, he wants to declare that, 'I am important, I am in power here and I have power over you' (L. Dian, 2016). 'Standing with hands on hips is an attempt to maintain dominance or intimidate others' (Reiman, 2007). While inserting hands into pants pocket is the development of hand movement gesture at the waist. This body language is just more specific by inserting the hands into the pocket as if there is something hidden. Hiding the hands is identical to hiding something (Ramdani, 2015).

When they insert their hands into the pants pocket by positioning the thumb out of the pocket, it has an aggressive meaning and to create the impression of very high position (Wahyuningtyas, 2015). Folding hands on the chest has the meaning that he feels himself the most righteous. The person who folds hands is a form of selfconfidence and consistency of the decision he or she has chosen (Ramdani, 2015). By feeling the most righteous, the person who does this gesture usually does not listen or care about the opinions of others. The examples of this gesture is often seen when someone is feeling upset and does not want to talk much to the other person.

The gesture of cuffing the waist, inserting hands into pocket, folding hands across the chest, and the sharp eyes look are shown by the models in Sunsilk Co-creations print advertising. In the culture and customs of Indonesia, gestures of cuffing waist, folding hands across the chest, and inserting hands into the pants pocket are considered impolite if they are done when meet a more respected person (L. Dian, 2016). In fact, eliciting gesture that is considered inappropriate to offend others, then the credibility of the person will be negatively valued. If there are some gestures that seem less sensitive and negative, it will undermine our credibility in front of people (L. Dian, 2016). 
Indeed, the Indonesian people who see the advertisement realized the gesture that was deliberately displayed in the advertisement wants to show and give an assessment in the self that the modeling persons are the boss who governs and we who witness it are the subordinate who must believe and follow his orders.

5. Business Casual Clothing Symbol

The reality is that person will see his appearance before knowing his personality in the first meeting. Your own definition of dressing should be based on the way you want to be perceived by others and your interest in growing within your organizations (Sabath, 2004).

The example of clothing contained in the models is business casual fashion model. A website about business fashion states what women and men use when they use business casual fashion model:

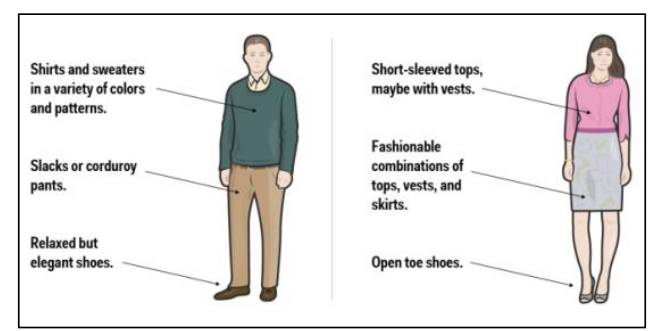

Image 3. Business Casual

(Kompas, 2017)

In Indonesia, the fashion model like the picture above is usually used by people who work in the office, who conduct business trip, who perform meeting with colleague that can be interpreted this type of fashion is a type of casual fashion for business people. So the model shown in Sunsilk Co-creations print advertising wants to be interpreted by the readers as a professional person that can not be underestimated. Although one's ability is not determined by the style of dressing, but the way of dressing affects one's perception of quality. However, those who prefer business attire feel most productive and trustworthy when wearing casual attire (Paludi, 2013).

The use of business casual attire in Sunsilk Co-creations print advertising includes representing orientalism because remembering in Indonesia itself the use of business casual attire model is a person who works in office, great and established. To achieve high profession in the office should be provided with high education. Higher education will affect their livelihood, the higher the education the level of the work to be gained will be higher (Ipeh et al, 2011).

Considering the price of the business casual attire model sold in the market, it proves that the level of Indonesian ability in buying and using the fashion model is still less than the models displayed by Sunsilk originating from the west. Economic status is the power or position of someone in the community, that socioeconomic status is the description of the state of a person or a socially viewed society, this description is like the level of education, income and so on.

According to the researchers, based on the meaning of the use of this fashion model, Indonesian people must have the desire to improve the quality of self. Not only admiring and looking great, but it should become motivation to move to be a 'great person', that is meant to have an education so as not to be underestimated and can be synchronized with international capability. 


\section{Typography Symbol of 'Co-Creations'}

Typography in the context of visual communication design involves the selection of the letters shape, the letters size, the ways and the technique of composing letters into words or sentences according to the character of the message to be conveyed (Tinarbuko, 2009). The writing of co-creations uses a kind of collection of small lights forming co-creations letters with silver-colored Uppercase writing under the advertising. This type of letters is decorative letters, i.e the letters are made in detail, complex, and complicated (Hendratman, 2006).

Making the letters light, giving the impression of brightening. Given the color shown in typography does not use many colors, only black on the background, grey and white on the lights, the ornament of the lamp gives the impression of brightening, exclusive, charming, and sparkling. The typography content on this effect is vary widely, depend on the effect of the object. In addition, it can also mean professional because the lamp is the type usually found in make-up mirror. This is reinforced by one of the lecturers of FSRD ITB as follows:

"That's make-up lights for make-up. Well, there is lamp near glass deck, it's special for us to see, it means no other function but for make-up. If it is associated with shampoo, it may have meaning to reinforce. It is as if the shown is professional and exclusive" (Harifa Ali Akbar, Lecturer of FSRD ITB on July 15, 2017 at CADL ITB Building).

Then Sunsilk put the text 'SUNSILK CO-CREATIONS' to give the impression that Sunsilk Co-creations is a new innovation that provides enlightment or answers to the confusion of female hair problems. It represents orientalism by showing that the eastern people have not been able to give enlightment on the hair.

7. Black Background Symbol

The use of color in an advertisement also affects the message to be conveyed or already entered into the discussion of color psychology. This advertisement uses dark shades color, that is black. Black is the color that belongs to the dark color group. Dark light in design is as one way to accentuate messages or information that can also add dramatic impression (Anggraini \& Nathalia, 2014).

According to Basuki's research on the meaning of colors in the design that the black color usually has negative connotative meaning. But black is strength and power; this color is often used to convey the impression of formal, elegant, and proud (Basuki, 2017). Black itself is considered as a color that give rise to the impression of dominant and strength. Black has bad reputation. This color is used by criminals in comic or film. So Sunsilk wants to show the dominant strength in the whole that Sunsilk displays in Sunsilk Co-creations print advertising, either from the quality of the product or the innovations it makes.

With the meanings, there is representation of orientalism because Unilever as the advertising maker is in the western and convey this advertising to Indonesia which becomes the target of its advertisement to interpret Indonesia as the eastern people as its communicant. It is interpreted that Sunsilk wants to show its dominant power and underestimate the eastern people who are considered to have no power like the western.

\section{Conclusion}

In Sunsilk Co-creations print advertising, the symbols consisted of 7 symbols, i.e symbol of 7 stranger models, symbol of 7 hair experts, text symbol 'Partnered with 7 of The Best Experts in The World - to Create The Best Ever Sunsilk', gesture symbol of 
keen gaze, cuffing waist, inserting hands into pocket, and folding hands avross chest, symbol of business casual attire, typographic symbol of 'Co-creations', and the symbol of black background.

The whole meaning has a unified thread of unity meaning, i.e there is a party that is shown dominant (the western people) and the other party becomes inferior (the eastern people). It can be seen from the dominant selection of models of hair experts on Sunsilk Co-creations print advertising are from the West than from the East. From the text side it is very clear that the use of Language used is foreign language or English in Indonesia that has its own language. For gestures and clothing, it can be seen that it is often done or used by people who feel they have more power than their interlocutors (that is, between the audience who sees the advertising and the model shown). Nor from typography and color selection that has exclusive and dominant meaning that gives the impression of difference level with the hair expert or other similar products.

Of all the meanings present in the symbols, they have in common that Sunsilk Cocreations print advertising represents orientalism because in its advertisement made by Unilever Brand Development has the value of glorifying Western people as seem to be the superior who consider the Eastern people, especially Indonesia is inferior. It is shown in all existing symbols.

\section{Acknowledgement}

By praising and thanksgiving to Allah SWT, for all His grace and blessings. In the process of this research, there are many guidance, prayers, criticism, and suggestions from various parties, so the researchers will not forget to thank our parents who keep supporting and accompanying during the process of this research until finish. Thanks also to all parties of Faculty of Communication Sciences, Universitas Padjadjaran which have always been the shelter of science to make this research. To Harifa Ali Akbar Siregar M.Ds, Lecturer of FSRD ITB, thanks for being triangulator in this research so as to facilitate the researchers in doing this research.

\section{References}

Dian, L. (2016). I Know Your Gesture. Yogyakarta: Pustaka Baru Press.

Foss, K. A. \& Littlejohn, S. W. (2008). Theories of Human Communication. Belmont: Thomson Wadsworth.

Hendratman, H. (2006). Computer Graphics Design. Bandung: Informatika.

Nöth, W. (1995). Handbook of Semiotics. Bloomington: Indiana University Press.

Olson, S. (2002). Mapping Humas History: Discovering the Past through Our Genes. New York: Mariner Book.

Paludi, M. A. (2013). Psychology for Business Success. England: Praeger.

Piliang, Y. A. (2003). Hipersemiotika: Tafsir Cultural Studies atas Matinya Makna. Bandung: Jalasutra.

Ramdani, Z. P. (2015). Gesture: Mengungkap Makna di Balik Bahasa Tubuh Orang Lain dan Mikroekspresi hingga Makroekspresi. Klaten: PT HAFAMIRA.

Reiman, T. (2007). The Power of Body Language: How to Succeed in Every Bussiness and Social Encounter. New York: Pocket Books.

Sumarwan, U. (2003). Perilaku Konsumen - Teori dan Penerapannya dalam Pemasaran. Jakarta: Ghalia Indonesia.

Azis, A. A., Cangara, H., \& Bahfiarti, T. (2015). Konstruksi Pencitraan Maskulinitas pada Majalah Men'S Health Indonesia versus Feminitas Pada Majalah Women'S 
Health Indonesia. Jurnal Kareba, 4(4): 399-414.

Fanani, F. (2011). Mitologi dalam Video Game: Pesan-Pesan Politik dalam Video Games Amerika Serikat. Jurnal The Messenger 3(1).

Hafiar, H., Mahameruaji, J. N., \& Rahmawan, D. (2017). Analisis Semiotika pada Cover Novel Trilogi karya Vira Safitri. Jurnal Nomosleca 3(April).

Nuswantara, J. P. (2014). Pesan Sosial dalam Foto Jurnalistik (Analisis Semiotika dalam Buku 'Jakarta Estetika Banal', Bab I, III, V dan VII). Jurnal The Messenger 6(1): 14-21.

Pebrianti, F. (2013). Penggunaan Diksi pada Iklan Produk Unilever di Stasiun Televisi SCTV. Jurnal Bahasa dan Sastra, 2(2): 1-15.

Sabath, A. M. (2004). Beyond Business Casual: What to Wear to Work if You Want to Get Ahead. Limcoln: ASJA Press.

Stephanie, R. F. (2014). Representasi Mooi Indie (Hindia Molek) dalam Iklan Pariwisata Indonesia. Jurnal Ilmu Komunikasi. http://e-journal.uajy.ac.id/6577/

Taha, M. H. (2014). Gratifying the 'Self' by Demonizing the 'Other': A Call for Dialogue not Monologues. J. Sage: 1-13. http://journals.sagepub.com

Tinarbuko, S. (2009). Semiotika Komunikasi Visual. Yogyakarta: Jalasutra.

Wardyaningrum, D. (2012). Penggunaan Daya Tarik Emosional pada Iklan Pajak di Televisi. Jurnal Al-Azhar Indonesia Seri Pranata Sosial, 1(4): 249-258.

Basuki, A. (2015). Makna Warna dalam Desain. Retrieved April 30, 2017, from http://basuki.lecturer.pens.ac.id/lecture/MaknaWarnaDalamDesain.pdf

Darry, M. (2013). Orientalisme. Retrieved May 21, 2016, from http://mohammad-darryfisip12.web.unair.ac.id/artikel_detail-79327-Ide\%20\%20Ide\%20Politik\% 20Alternatif-Orientalisme.html

Hazan, R. (2016). About Us. Retrieved December 25, 2016, from https://ritahazan.com/pages/about-us\#rita

https://www.hamadibeauty.com/pages/meet-jamal

http://mohammad-darry-fisip12.web.unair.ac.id/

http://www.rudyhadisuwarno.co.id/about-us

http://www.wexlerdermatology.com/meet-our-experts/francesca-fusco\#sthash. hIY1qLqQ.dpbs

Ipeh dkk. (2011). Pengaruh Tingkat Pendidikan Masyarakat terhadap Jenis Pekerjaan di Kecamatan Ngemplak Kabupaten Boyolali. Retrieved May 30, 2017, from http://ipahipeh.blog.fisip.uns.ac.id

Markaz Production. (2015). Syarat Untuk Menjadi Model. Retrieved May 24, 2017, from http://markaz-production.com/syarat-untuk-menjadi-model/

Nasution, J. (2017). Membaca Pikiran Seseorang Lewat Bahasa Tubuh. Retrieved May 30, 2017, from http://www.academia.edu/25860877/Membaca_Pikiran_Seseorang_Lewat_Bahas a_Tubuh

Ouidad. (2016). Our Heritage. Retrieved December 25, 2016, from https://www.ouidad.com/our-heritage

Sunsilk. (2016). Retrieved December 23, 2016, from http://www.sunsilk.in/

Sunsilk. (2016). Teddy. Retrieved December 25, 2016, from https://www.sunsilk.in/experts/teddy.html

Sunsilk. (2016). Thomas Taw. Retrieved December 25, 2016, from http://www.sunsilk.co.id/artikel/detail/1153632/thomas-taw

Sunsilk. (2016). Yuko Yamashita. Retrieved December 25, 2016, from 
http://www.sunsilk.co.id/artikel/detail/1153625/yuko-yamashita

Sunsilk. (2016). 7 Sunsilk Experts. Retrieved March 25, 2016, from http://www.sunsilk.com.pk/7-sunsilk-experts/

Wahyuningtias, D. (2017). Peran Gesture (Gerak Tubuh) Guru sebagai Upaya Menumbuhkan Perhatian Siswa pada Pembelajaran Pendidikan Agama Islam di Sekolah Menengah Kejuruan Ketintang Surabaya. Skripsi. Retrieved April 28, 2017, from http://digilib.uinsby.ac.id/2198/5/Bab\%202.pdf

Wibawa, S. W. (2016). Apa Arti Kode Busana 'Business Casual'? Retrieved April 2, 2017 , from http://lifestyle.kompas.com/read/2016/07/05/190400620/apa.arti.kode.busana.busi ness.casual

Wicaksono, B. D. (2016). Ini 8 Alasan Kenapa Banyak Orang Indonesia Mudah Percaya Hoax atau Kabar Bohong. Retrieved May 20, 2017, from https://hype.idntimes.com/viral/bayu/ini-8-alasan-kenapa-banyak-orangindonesia-mudah-percaya-hoax-atau-kabar-bohong/full 